\title{
The Use of Probiotic and Antioxidants to Improve Welfare and Production of Layer Duck at Commercial Farms for Global Warming Mitigation
}

\author{
Imam Suswoyo ${ }^{1,{ }^{*}}$, Ismoyowati Ismoyowati $^{1}$, Wahyu Widodo $^{2}$, and Zane Vincēviča-Gaile ${ }^{3}$ \\ ${ }^{1}$ Department of Animal Production, Faculty of Animal Science, Jenderal Soedirman University, \\ Jl. Profesor DR. HR Boenyamin No.708, Banyumas 53122, Central Java, Indonesia \\ ${ }^{2}$ Department of Animal Science, Faculty of Agriculture and Animal Science, \\ University of Muhammadiyah Malang, Jl. Raya Tlogo Mas no.246. Malang 65144, \\ East Java, Indonesia \\ ${ }^{3}$ Department of Environmental Science, University of Latvia, Jelgavas Street 1, Room 302, \\ Riga LV-1004, Latvia
}

\begin{abstract}
Global warming affected increasing the risk of ducks to be more succeptable to heat stress which leads to decrease welfare and production. This research aimed to study duck welfare and productivity under probiotic and antioxidants administration at commercial farms. The method used was experiment with Completely Randomized Designed (CRD) based on factorial pattern. The treatment was dose of natural/homemade and commercial probiotics combined with vitamin $\mathrm{C}$ at $400 \mathrm{mg} \mathrm{kg} \mathrm{g}^{-1}$ and $600 \mathrm{mg} \mathrm{kg}^{-1}$ feed. Thus there were four treatment combinations. Each treatment was replicated five times, totally were 20 flocks of duck. Each flock had 50 laying females so there were 1000 ducks. The treatment was conduced for 2 mo. The parameters observed included, i) duck welfare based on Heterophyl/Lymphocyte $(\mathrm{H} / \mathrm{L})$ ratio; ii) egg production consisted of (a) duck day production, and (b) egg weight. This study concluded that administration of combination between homemade probiotic and vitamin $\mathrm{C}$ at $600 \mathrm{mg} \mathrm{kg}^{-1}$ feed significantly $(p<0.05)$ increased duck welfare and egg production but did not affect egg weight.
\end{abstract}

Key words: Heat stress, increase duck welfare and egg production, local ducks, vitamin C

\section{Introduction}

High ambient temperature is a serious obstacle in developing poultry production in tropical areas, especially in recent climate change phenomenon. Climate change now is one of big issues concerns to the world. It is understood since climate change has severe impact not only for human being but also animal. Indonesian National Aviation and Space Agency reported that the climate in Indonesia has become warmer during the 20th century with an average annual temperature has increased by about $0.3{ }^{\circ} \mathrm{C}$ since 1900 [1]. Ducks, as a homeotermic animal, is succeptable to heat stress which leads to decreasing its welfare and productivity. Previous study reported that under dry intensive system, local ducks suffered from heat stress as indicated by rectal temperature, behaviour, and body and plumage

\footnotetext{
*Corresponding author: suswoyo_01@yahoo.com
} 
condition [2]. Therefore, releasing heat stress is an essential factor to improve duck welfare. Recently it has been proven that oxidative stress is a molecular mechanism of many different stresses, including environmental stresses (e.g. heat stress), nutritional stresses (e.g. mycotoxins) and internal stresses (e.g. bacterial, viral, etc.) [3]. Manipulation on daily management is required to protect the ducks from suffering from heat stress, among others by using vitamins as functional feed.

Several studies have been conducted to investigate the use of probiotic and vitamins for alleviation of heat stress in poultry. In broiler chickens, probiotic Lactobacillus strains have proven to be able to restore the microbial balance and maintaine the natural stability of indigeneous bacterial microbiota following heat stress-induced changes [4]. Under heat stress conditions, chickens fed with diets containing Lactobacillus cultures have higher antibody production than those on control diet [5]. Supplementation of probiotic in diet significantly increases white blood cells count and decreases Heterophyl/Lymphocyte (H/L) ratio which is important in reduction of stress effect in poultry [6]. Relating to heat stress, probiotic might be useful for ameliorating the adverse influence of heat on the egg production and the gut health of laying hens [7].

The most important and well-characterised natural antioxidants in the animal body are vitamins $\mathrm{E}$ and $\mathrm{C}$. All antioxidants are responsible for prevention of the damaging effects of free radicals and toxic products of their metabolism [8]. [9] Stated that in broiler chicks, optimal antioxidant supplementation is shown to be important to maintain growth rate, immunocompetence and meat quality. Whereas in broiler chickens, supplementation of $250 \mathrm{mg} \mathrm{kg}^{-1}$ vitamin $\mathrm{C}$ was the most effective in reducing heat stress [10]. Recently it has been proven that vitamin $\mathrm{C}$ (ascorbic acid) - an important antioxidant synthesised in chickens and its dietary supplementation is shown to be effective in stress conditions, when its requirement substantially increased. [9]. Some studies have shown that vitamin $\mathrm{C}$ has been reported to enhance immune response by modifying corticosteroid synthesis in adrenal glands [11]. Most previous studies, however, concerned on vitamins use for chickens. Thus, study on effect of probiotic and vitamin combination on duck welfare is lacking, especially that under commercial farm management.

Keeping this in mind, this study was conducted to examine the effect of probiotic and vitamin $\mathrm{C}$ combination on welfare and egg production of local ducks kept in commercial farms.

\section{Materials and methods}

\subsection{Methods}

This study used experimental method that conducted in collaboration with 'Berkah Abadi' duck farmer group and ducks reared under dry system intensively. Under intensive system, the ducks are mostly kept in sheds with rice straw bedding and solid floor ranch infront of the sheds [12]. The study was located at Tegal City, Central Java, Indonesia which is located in the northern coastal area of Java Island. The City and its surrounding areas is one of the most important duck centers in Indonesia with its very famous local layer duck namely Tegal Duck. It is believed that the duck belongs to Indian Runner family. 


\subsection{Materials and methods}

The materials used was local layer ducks which the age of $13.4 \mathrm{mo} \pm 1.3 \mathrm{mo}$. Intensive system refers to the conventional reraing by the farmers in which ducks were confined around the farmer's village by closed fence. Hence ducks had no access to the outside area, and the amount of feed provided could be controlled and measured. Drinking water was provided ad libitum three times a day i.e. in the morning, noon, afternoon, while feed was given twice a day i.e. in the morning and in the afternoon. The feedstuffs were locally available which mainly consisted of rice bran, dried rice, and fresh fish (Leiognathidae T. N. Gill, 1893) with proportion of $39.65 \%, 25.11 \%$ and $35.24 \%$ respectively. The nutrient content were $26.38 \%$ crude protein, $2.923 \mathrm{kcal} \mathrm{kg}^{-1}$ metabolic energy, $2.29 \%$ Calcium and $0.78 \%$ Phosphorus.

This study used Factorial method with treatments consisted of combinations between three doses of home-made (H) and commercial probiotics (C) with vitamin C 400 (C1) and 600 (C2) $\mathrm{mg} \mathrm{kg}$ feed. There were four treatments units were replicated five times. Thus, totally were 20 flocks. Each flock had 50 female ducks; therefore this study involved 1000 ducks. The treatments were applied each morning, mixed thoroughly in duck ration.

\subsubsection{Data collected:}

i. Heterophils to lymphocyte $(\mathrm{H} / \mathrm{L})$ ratio as a welfare status Blood samples were taken from two ducks per flock for determination of $\mathrm{H} / \mathrm{L}$ ratio on $60^{\text {th }} \mathrm{d}$ of the study.

ii. Daily ambient air temperature and humidity as indicators of environmental condition were measured at $6 \mathrm{am}$, noon, and $3 \mathrm{pm}$.

iii. Laying percentage/duck day production (expressed as average number of eggs laid per day in relation to number of female ducks flock ${ }^{-1}$ ), and average egg weight (g) flock ${ }^{-1}$ as indicators of egg production.

\subsubsection{Data analysis:}

Data collected were analyzed using Analysis of Variance (ANOVA) and followed by Honestly Significant Different (HSD) test if any different effects.

\section{Results and discussions}

Blood H/L ratio, duck day production (DDP), and egg weight during this study were summarized in Table 1 below.

Table 1. H/L ratio, DDP, and egg weight during the study

\begin{tabular}{|l|c|c|c|c|}
\hline \multirow{2}{*}{\multicolumn{1}{|c|}{ Parameters }} & \multicolumn{4}{c|}{ Treatments } \\
\cline { 2 - 5 } & HC1 & HC2 & CC1 & CC2 \\
\hline H/L Ratio & $0.56 \mathrm{a}$ & $0.55 \mathrm{a}$ & $0.75 \mathrm{~b}$ & $0.61 \mathrm{~b}$ \\
\hline DDP (\%) & $72.04 \mathrm{a}$ & $68.75 \mathrm{~b}$ & $64.40 \mathrm{~b}$ & $66.39 \mathrm{~b}$ \\
\hline Egg weight (g) & $67.28 \mathrm{a}$ & $68.98 \mathrm{a}$ & $69.35 \mathrm{a}$ & $70.61 \mathrm{a}$ \\
\hline
\end{tabular}

Note: numbers at the same row with different alphabet indicate significant differences $(p<0.05)$.

\subsection{Duck welfare}

$\mathrm{H} / \mathrm{L}$ ratio in this study ranges from 0.32 . to 1.14 with an average of $0.62 \pm 0.09$. Statistical analyses indicated that $\mathrm{H} / \mathrm{L}$ ratio in $\mathrm{HCl}$ was significantly $(p<0.05)$ lower than that in 
other treatments. It indicated that combination of home-made probiotic and vitamin $\mathrm{C}$ supplementation has improved duck welfare. Figure 1 presents the average of $\mathrm{H} / \mathrm{L}$ ratio of each group of treatment.

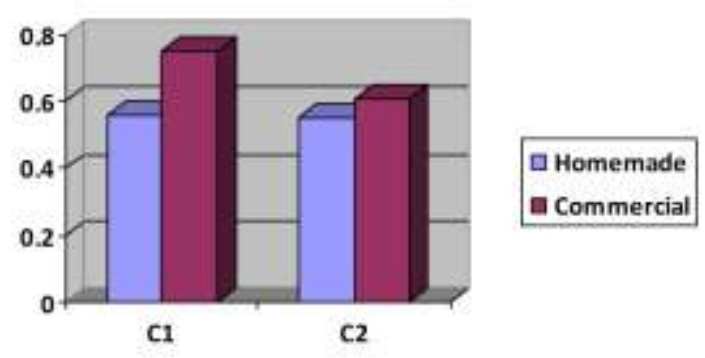

Fig. 1. The average of $\mathrm{H} / \mathrm{L}$ ratio of each group of treatment

Results of this study indicate that ducks supplemented with combination of home-made probiotic and vitamin $\mathrm{C}$ had lower $\mathrm{H} / \mathrm{L}$ ratio which means that the ducks were more welfare. [13] Stated that ducks in welfare condition has lower H/L ratio than those in stress condition.

\subsection{Egg production}

Average egg production was $66.99 \% \pm 3.29 \%$ ranging from $47.86 \%$ to $87.14 \%$. This finding confirms that previous results of $[2,14]$. Egg production of control and treatment groups presented in Figure 2.

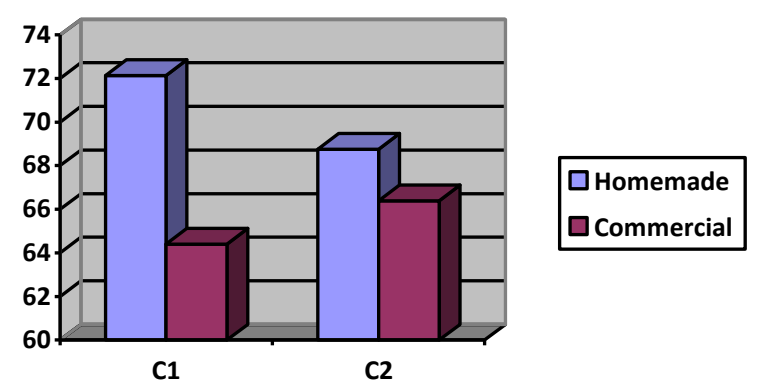

Fig. 2. Egg production of control and treatment groups

Statistical analysis showed that combination of home-made probiotic and vitamin $\mathrm{C}$ supplementation significantly $(p<0.05)$ increased duck day production. It seems that that the dose was the most effective quantity for supplementation. High requirement of vitamin occurs when poultry under stress condition since it has vital roles in metabolic reactions. One of the most crucial factor of vitamin $\mathrm{C}$ is in amino acid metabolism which affect egg production.

\subsection{Egg weight}

Egg weight ranges from $61.80 \mathrm{~g}$ to $75.20 \mathrm{~g}$ with an average of $69.05 \mathrm{~g} \pm 1.37 \mathrm{~g}$. This finding was confirmed the results of previous research which found that egg weight 
was $71.14 \mathrm{~g} \pm 6.08 \mathrm{~g}$ [14]. The lowest egg weight was found at control ducks although it us not significant $(p>0.05)$. Figure 3 presents the average of egg weight during the study.
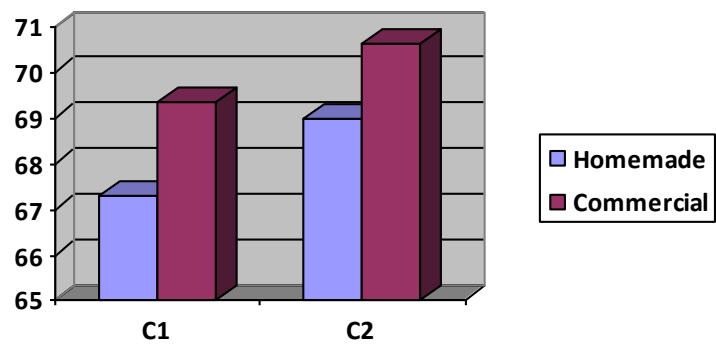

Fig. 3. The average of egg weight during the study

\subsection{Environmental condition}

Environmental condition at study site is presented in Table 2.

Table 2. Average ambient temperature and humidity at location study

\begin{tabular}{|l|c|c|c|c|}
\hline $\begin{array}{c}\text { Environmental } \\
\text { condition }\end{array}$ & Morning & Noon & Afternoon & Average \\
\hline Temperature $\left({ }^{\circ} \mathrm{C}\right)$ & $27.06 \pm 0.64$ & $31.91 \pm 0.89$ & $31.35 \pm 0.85$ & $29.35 \pm 2.65$ \\
\hline Humidity $(\%)$ & $88.94 \pm 3.81$ & $79.43 \pm 5.76$ & $82.32 \pm 3.50$ & $83.56 \pm 4.88$ \\
\hline
\end{tabular}

Table 2 indicates that environmental temperature of the study site was $29.35{ }^{\circ} \mathrm{C} \pm$ $2.65{ }^{\circ} \mathrm{C}$ on average which was higher than the maximum temperature needed by poultry. Study site which was coastal region of Tegal City, Central Java, Indonesia is considerably suffer from climate change. At the same time relative humidity was also high with average of $83.56 \% \pm 4.88 \%$. It seems that environmental condition in the area was higher than the thermo-neutral zone required by ducks. Thermo-neutral zone for poultry is between $18{ }^{\circ} \mathrm{C}$ to $25{ }^{\circ} \mathrm{C}$, and the most efficient temperature for ducks ranges between $23{ }^{\circ} \mathrm{C}$ to $25{ }^{\circ} \mathrm{C}$ [15]. Figure 4 presents the variation of average daily ambient temperature and humidity during the study.

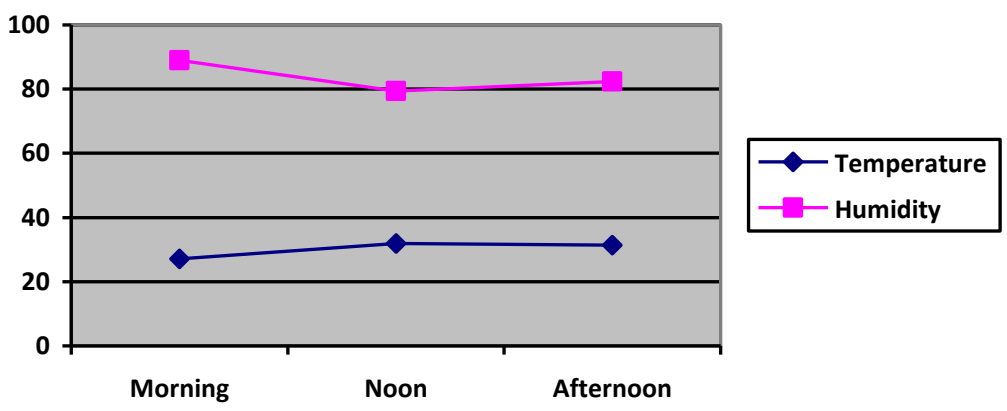

Fig. 4. Variation of average daily ambient temperature and humidity during the study 
Controlling the ducks' environment, particularly temperature, humidity, litter moisture and ammonia is crucial to duck welfare [16]. If the ambient temperature is higher than the thermoneutral zone, panting will increase ten times which decreases productivity [17]. Qualitative observation along the study showed that ducks with treatments had more comfort condition indicated by less drinking and panting activities.

\section{Conclusions}

On commercial level, that administration of three doses of home-made probiotic and $600 \mathrm{mg} \mathrm{kg}^{-1}$ vitamin $\mathrm{C}$ has improved duck welfare and egg production, but did not increase the egg weight.

The authors would thank to the Directorate General of Higher Education and Rector of Jenderal Soedirman University for funding this research. The deepest thank also to duck farmers of 'Berkah Abadi' group who made this study done.

\section{References}

1. LAPAN. Perubahan iklim: Penyebab, dampak dan antisipasi [Climate change: Causes, impacts and anticipation]. Bandung: Pusat Sains dan Teknologi Atmosfer (2017). p. 5-51. [in Bahasa Indonesia]. http://psta.lapan.go.id/files_uploads/buletin/Vol.2_No.2_Jul-Des2017.pdf

2. I. Suswoyo, Ismoyowati, I.H. Sulistyawan. Int. Jou of Poul. Sci. 13,4: 214-217(2014).

https://www.researchgate.net/publication/272964487_Benefit_of_Swimming_Acc ess_to_Behaviour_Body_and_Plumage_Condition_and_Heat_Stress_Effect_of_L ocal_Ducks

3. P.F. Surai, V.I. Fisinin. Agricultural Biology. 4:3-13(2012). https://doi.org/10.15389/agrobiology.2012.4.3eng

4. S. Yadav, R Jha. J Animal Sci Biotechnol. 10,2:1-11(2019). https://doi.org/10.1186/s40104-018-0310-9

5. H. Al-Khalaifa, A. Al-Nasser, T. Al-Surayee, S. Al-Kandari, N. Al-Enzi, T. Al-Sharrah, et al. Poultry Science. 98,10:4465-4479(2019). https://doi.org/10.3382/ps/pez282

6. S.H. Rahimi, A. Khaksefidi. Iranian Journal of Veterinary Research. 7,3: 23-28(2006). https://dx.doi.org/10.22099/ijvr.2006.2645

7. K. Deng, C.W. Wong, J.V. Nolan. Jou. of Anim. Phys. and Anim. Nutr. 90, 1-2:81-86(2006). https://doi.org/10.1111/j.1439-0396.2005.00569.x

8. P.F. Surai. Natural antioxidants in poultry nutrition: new developments. Proceedings of the 16th European Symposium on Poultry Nutrition, (Scotlandia, UK 2007). Proceedings of the 16th European Symposium on Poultry Nutrition. 669-676(2007).

http://www.feedfood.co.uk/download/1_Europ_Strasbourg_Symposium_2007.pdf

9. A.A. Fotina, V.I. Fisinin, P.F. Surai. Bulg J. Agric. Sci. 19,5:889-896(2013). http://www.feedfood.co.uk/download/Bulgarian_Performax_2013.pdf

10. E. Kusnadi. JITV. 11,4:249-253(2006). [in Bahasa Indonesia]. http://oaji.net/articles/2015/1610-1424247036.pdf

11. N. Bhatti, Z. Hussain, M. Mukhtar, A. Ali, M. Imran, A. Rafique, et al. Journal of Antivirals \& Antiretrovirals. 8,4:151-154(2016). https://doi.org/10.4172/jaa.1000152 
12. P.P. Ketaren. Wartazoa. 17,3:117-127(2007) (in Bahasa Indonesia). http://medpub.litbang.pertanian.go.id/index.php/wartazoa/article/view/877/886

13. I. Suswoyo, Rosidi. International Journal of Poultry Sci. 15,6:235-239(2016). https://doi.org/10.3923/ijps.2016.235.239

14. I. Ismoyowati, D. Indrasanti, I.H. Sulistyawan. Buletin Peternakan. 42,3: 197-202(2018). https://doi.org/10.21059/buletinpeternak.v42i3.34465

15. A.S.O. El-Badry, M.M. Hassanane, E.S. Ahmed, K.H. El-Kholy. Global J. Biotech. \& Biochem. 4,2:152-159(2009).

http://citeseerx.ist.psu.edu/viewdoc/download?doi=10.1.1.482.7693\&rep=rep1\&ty pe $=$ pdf

16. T.A. Jones, M.S. Dawkins. British Poul. Sci., 51,1:12-21(2010). https://doi.org/10.1080/00071660903421159

17. T. Ahmad, M. Sarwar. Feed Mix (The International Journal on Feed, Nutrition and Technology). 13,4:15-17(2005).

https://scholar.google.co.id/scholar?hl=id\&as_sdt=0\%2C5\&q=Dietary+electrolyte $\underline{\mathrm{s}+\text { combat }+ \text { heat }+ \text { stress }+\mathrm{in}+\text { broilers } \& \text { btnG }=}$ 